\title{
F. Paul Richardson: In Memoriam
}

Francis Paul Richardson sadly died on 30 April 2009 at the age of 88 . For many years Paul was very actively engaged in both traditional librarianship through his activities in the Library Association and in law librarianship as an early and very active, member of BIALL.

Paul was born on 10 April 1921. He was educated at Loughborough Grammar School and started his career in librarianship in Loughborough in 1937. During the Second World War he served in the RAF and then in the Royal Air Force Regiment when it was formed in 1942. and was then part of the first intake of students at Loughborough Library School in 1946-47. He became a Chartered Librarian in 1948 and a Fellow in 1968. His work in law librarianship began when he became Central Lending Librarian, with responsibility for law, at Hammersmith Public Library in 1975. He became the Librarian of the Law Society in 1969, co-incidentally the year in which BIALL was founded and remained there until his retirement in 1957.

\section{BIALL}

Paul was one of the earliest members of BIALL and, until ill health restricted his activities in 1976, he had been a key member of the Association. He was a member of the Committee which produced our first policy document and publication - the Report of the Committee on Co-operation (197I). As a result of this report, several committees were set up during 197I-72. One was the Sub-Committee on Acquisitions and Storage and another was the Standing Committee on Education and Training. Paul was a member of the former from its inception till late 1975. He was the first Chairman of the latter and remained a member until 1978. During his Chairmanship, he organised with Don Daintree our first one-day seminar entitled Educating the Library User and held at Trent Polytechnic in June 1972. Paul was also a tutor on our first week-end course on legal literature held at the University of Hull in 1974.

He was involved in the publication of the Bibliography on Community Law (1973) and the memorandum on the Provision for Law in the British Library (1974). He also contributed the chapter on reader services to the first edition of the Manual of Law Librarianship.

In late 1972 Paul was appointed to a small subcommittee to prepare a memorandum on the staffing and administration of court libraries, which was submitted to the Lord Chancellor's Department in the same year and was published in the Law Librarian Vol. 6, 1975, Pp. 2224. Paul was also involved in obtaining BIALL representation on the HMSO Service Working Party and was our representative in 1972-73 and 1976-77.
In 1972 he was elected to the Executive Committee and in 1974 he was appointed Chairman-Elect. In those days, the Chairman served for more than one year. Paul began his term of office in 1975 but unfortunately, due to ill health, he only served for one year, resigning to consternation all round at the annual conference held in September 1976 at New College Oxford, thus precipitating the first "constitutional crisis" of the Association's history. He was accompanied to the Conference by his wife, Tina, and this was probably the first occasion on which many BIALL members met her. He continued to contribute to BIALL's work as an ex-officio member of the Executive Committee, making considerable contributions to the revised Constitution and Regulations of 1983.

Paul retired from the Law Society Library in 1985 and Council elected him as an Honorary Life Member in the same year, in recognition of his great services to the Association.

\section{Other professional activities}

Paul was also an active member of the Library Association, holding the office of Councillor from 1983, and serving on the Manpower Services Standing Committee and the Disciplinary Committee.

\section{Personal life}

After the Second World War Paul was an active supporter of the Royal Air Force Regiment Association and he also supported the Royal British Legion throughout his life. In retirement, Paul was an active member of various Catholic organisations and assisted at his local church, St Edwards. $\mathrm{He}$ also sang in a choir and enjoyed a game of bowls.

\section{Personal tribute}

Paul was well-known in the late 1970s and early 1980s to us then young law librarians, as almost a father figure, who was deeply concerned for his staff's welfare, whilst also running the Law Society Library with a rod of iron. When Diane Raper took over from him as Librarian in 1985, she found an extremely well-run library which had a superb card catalogue, containing excellent subject headings, which meant that it was easy to locate material and to answer efficiently the type of enquiries the Law Society Library dealt with in those days.

Paul also displayed innovative skills - it was he who, in the early days of Lexis, managed to establish a mediated service for solicitors who were members of the Society to access Lexis via the library staff. 
Whilst Paul could sometimes appear to be a slightly formidable person, particularly when one was undertaking committee work with him, as he was well-known for his strongly-held views and his insistence on adhering to the principles which he believed were right, he was at the same time a true professional. His attention to detail was legendary and he always expected high standards in any projects he was involved in.

He was the first professionally qualified librarian to be employed at the Law Society and he started the tradition of young law librarians cutting their teeth on legal information work in its comprehensive library. They then moved into the rapidly developing field of law firm information work, armed with excellent legal research skills.

$\mathrm{He}$ will be remembered with affection and he has left a lasting legacy in his early work for BIALL. We extend our condolences to his wife Tina and their daughter, in their sad loss.

Christine Miskin

With help from Diane Raper and Barbara Tearle

\section{BIALL Present and Future}

As part of our $40^{\text {th }}$ Anniversary issue we asked the immediate Past President of the Association, Jackie Fishleigh, to tell us what she felt the most important activities of the Association have been over the past year. We also asked Daniella King, now the President, to write about what she considers are the challenges the Association immediately faces.

\section{President's Report 2008-2009 Jackie Fishleigh}

Following the implementation of the new governance structure, 2008-2009 is the first year that BIALL has had a President rather than a Chair. It has been an honour to be the first person to be elected to this office.

We have also changed the Constitution to allow the electronic delivery of ballots. This was agreed at the AGM last year and approved by a postal ballot of members. The process of reform started as part of the Strategic Review is thus complete. I would like to thank everyone who has been involved in carrying out these important changes which should make the Association fit for purpose in the electronic age.

This leads me on to the major project of this year which has been the new website. Web developers Fat Beehive were selected to work with the Web Committee to design this for us. The website is now live. The Web Committee have put a great deal of work into this for which we are all most grateful. I hope you agree that having a state-of-the-art website will be of great benefit to the membership as a whole.

As everyone is no doubt well aware, this has been a difficult year financially both for organisations and individuals generally. We have been fortunate at BIALL that the great care taken with finances in previous years has left the Association with healthy balances in both our current account and reserve fund. This has enabled us to offer registration fees for our Manchester conference at even lower levels than 2006 and also to make available three times the usual number of bursaries to encourage attendance. Although numbers this year will undoubtedly be lower than last year due to deep cuts in training budgets at law firms, we are fortunate that very strong sponsorship and an excellent programme put together by an extremely hardworking conference Committee will see us through and make the event a success again this time.

The downturn has also led to a squeeze on active membership. This is understandable but we have made special efforts to maintain our traditionally high levels of member involvement. I am pleased to report that all the Officer and Council posts will be filled at the AGM. Committees have been the hardest hit but we have and will continue to undertake recruitment drives to address this.

I have been very impressed at the great range of skills and expertise amongst our members and at their level of commitment even when under pressure at work. We are very lucky to have such a pool of talent and we will continue to tap it vigorously!

The Future of BIALL.... Is there a Tarot Reader in the House? Daniella King

As a general rule, the most successful man in life is the man who has the best information.

- Benjamin Disraeli 